Canadian Journal of Plant Science Revue canadienne de phytotechnie

AAC W1876 Hard Red Spring Wheat.

\begin{tabular}{|r|l|}
\hline Journal: & Canadian Journal of Plant Science \\
\hline Manuscript ID & CJPS-2017-0326.R1 \\
\hline Manuscript Type: & Cultivar description \\
\hline Date Submitted by the Author: & 03-Jan-2018 \\
\hline Complete List of Authors: & $\begin{array}{l}\text { Cuthbert, Richard; Swift Current Research \& Development Centre, } \\
\text { Agriculture \& Agri-Food Canada } \\
\text { DePauw, R.; Advancing Wheat Technologies, } \\
\text { Knox, Ron; Agriculture \& Agri-Food Canada, Swift Current Research and } \\
\text { Development Centre } \\
\text { Singh, Asheesh; Iowa State University, Agronomy } \\
\text { McCaig, Tom; Agriculture and Agri-Food Canada, } \\
\text { McCallum, Brent; Cereal Research Centre, AAFC } \\
\text { Fetch, Thomas; Cereal Research Centre, Agriculture and Agri-Food Canada }\end{array}$ \\
\hline Keywords: & \begin{tabular}{l} 
Wheat, grain yield, disease resistance, semidwarf, quality \\
\hline
\end{tabular} \\
\hline
\end{tabular}




\title{
Cultivar Description
}

\section{AAC W1876 Hard Red Spring Wheat}

\author{
R.D. Cuthbert ${ }^{1 *}$, R.M. DePauw ${ }^{1,2}$, R.E. Knox ${ }^{1}$, A.K. Singh $^{3}$, T.N. McCaig ${ }^{1,4}$, B. \\ McCallum $^{5}$, and T. Fetch ${ }^{5}$
}

\begin{abstract}
${ }^{1}$ Agriculture and Agri-Food Canada, Swift Current Research and Development Centre, P.O. Box 1030, Swift Current, Saskatchewan, Canada, S9H 3X2; ${ }^{2}$ Advancing Wheat Technology, 870

Field Drive, Swift Current, Saskatchewan, Canada, S9H 4N5; ${ }^{3}$ Department of Agronomy, Iowa State University, Ames, IA, USA; ${ }^{4}$ retired; ${ }^{5}$ Agriculture and Agri-Food Canada, Morden Research and Development Centre, 101 Route 100, Morden, Manitoba, Canada.
\end{abstract}

* Corresponding authors: R.D. Cuthbert (email: Richard.cuthbert@agr.gc.ca) 
Cuthbert, R.D., DePauw, R.M., Knox, R.E., Singh, A.K., McCaig, T.N, McCallum, B., and Fetch, T. AAC W1876 Hard Red Spring Wheat. Can. J. Plant Sci. *****2018.

AAC W1876 hard red spring wheat (Triticum aestivum L.) has grain yield and time to maturity within the range of the check cultivars: Katepwa, Laura, Lillian, Carberry, and CDC Kernen. AAC W1876 has an awned spike, a low lodging score indicative of strong straw, and a short plant stature typical of a semidwarf wheat. AAC W1876 expressed resistance to prevalent races of leaf rust, moderate resistance to stem rust, intermediate resistance to fusarium head blight, yellow rust, common bunt, and loose smut. Compared to the Canada Western Red Spring check cultivars, AAC W1876 had improved flour yield and lower flour ash. AAC W1876 is eligible for grades of Canada Western Red Spring.

Key Words: Triticum aestivum L., wheat, cultivar description, grain yield, disease resistance, semidwarf, quality.

AAC W1876, a hard red spring wheat (Triticum aestivum L.) cultivar, was developed at the Swift Current Research and Development Centre (SCRDC), Agriculture and Agri-Food Canada (AAFC), Swift Current, SK. It received registration No. 7608 from the Variety Registration Office, Plant Production Division, Canadian Food Inspection Agency (CFIA) on 30 Sept, 2014. AAC W1876 was granted Plant Breeders' Rights certificate No. 5259 by the Plant Breeders' Rights office, CFIA on 16 May 2016.

Origin and Breeding: AAC W1876 was selected from the cross Prodigy/5602HR//Alsen made in 2004 at the SCRDC of AAFC in Swift Current, SK. The cultivar Prodigy (Graf et al. 2003), which derives from SWP2242/Stoa, was crossed to 5602HR, which derives from AC 
Barrie/Norpro. The parents were haplotyped using the molecular markers associated with Fusarium head blight (FHB) (Bokore et al. 2017). The $F_{1}$ plants were top crossed with Alsen (Frohberg et al. 2006). A total of 950 top cross $F_{1}$ seeds were increased in controlled environment facilities at SCRDC.

In the spring of 2005 , about $10,000 \mathrm{~F}_{2}$ seeds were inoculated with common bunt [Tilletia laevis Kühn in Rabenh., and T. tritici (Bjerk.) G. Wint. in Rabenh.] races L16 and T19 (Hoffmann and Metzger 1976), and space-planted at $10 \mathrm{~cm}$ intervals within a row in an irrigated epiphytotic field nursery near Swift Current. Genotypes susceptible to prevalent races of leaf rust (Puccinia triticina Eriks.) and stem rust (Puccinia graminis Pers.:Pers. f. sp. tritici Eriks. and E. Henn.) were planted as disease spreaders every tenth row. Between the spreader rows, five rows of spring planted winter wheat were alternated with four rows of $F_{2}$ seed at a row spacing of $23 \mathrm{~cm}$. The winter wheat cultivar CDC Kestrel (Fowler 1997), which is susceptible to leaf and stem rust, was used to contribute to the multiplication of rust inoculum. Spreader rows were inoculated by injecting, with a syringe and needle, a water suspension of leaf rust and stem rust spores into a sample of plants every $3 \mathrm{~m}$. Representative leaf rust races found the previous year were applied (McCallum and Seto-Goh 2006). Stem rust races used were: QTHJF (C25), RHTSC (C20), RKQSC (C63), RTHJF (C57), TMRTF (C10), and TPMKC (C53) (Roelfs and Martens 1988; Fetch et al. 2015). Leaf spot diseases developed through natural infection. Individual plants were selected relative to the range of the checks in the nursery for reduced plant height, improved standibility, maturity within the range of the checks in the nursery, and resistance to common bunt, leaf spot diseases, leaf rust, and stem rust. From the disease nursery, 308 disease-free, semidwarf statured, strong strawed, and early maturing $\mathrm{F}_{2}$ plants were selected, threshed individually, and further selected for kernel characteristics. 
The $\mathrm{F}_{3}$ seed of $251 \mathrm{~F}_{2}$ derived individuals was planted as $2 \mathrm{~m}$ long head-rows in a contra season nursery near Lincoln, New Zealand. From these, 135 lines were selected on the basis of comparable performance to the check cultivars for time to maturity, plant height, straw strength, and shattering. The selected rows were harvested as individual rows. These $\mathrm{F}_{2: 4}$ lines was grown in four-row plots with a harvested area of $2.76 \mathrm{~m}^{2}$ near Swift Current with two reps, and one rep at each of near Indian Head, and Regina, SK to assess agronomic performance. Agronomic plots were harvested at maturity and grain weight of each plot was measured. Each $\mathrm{F}_{4}$ genotype was also grown in a nursery near Portage La Prairie, MB and inoculated with Fusarium (Fusarium graminearum Schwabe (teleomorph Gibberella zeae (Schwein. Petch), leaf rust, and stem rust, followed by regular sprinkler irrigation as described by Bokore et al. (2017). The selection criteria combined over both nurseries were resistance to FHB, leaf rust, stem rust, common bunt, and leaf spotting diseases, strong straw of a semidwarf height, maturity within the range of the control cultivars, non-shattering spike attributes, and grain yield. Five spikes were collected from the FHB nursery plots of each $\mathrm{F}_{4}$ line which met the selection criteria as well as five spikes from all yield trial plots at Swift Current.

Of the selected lines, grain protein concentration and volume weight were measured on whole grain of each sample within each location using a Foss Infratec 1241 near infrared reflectance spectroscopy (Williams 1979) instrument, coupled with a test weight module. A subsample was submitted to the Central Quality Lab, Cereal Research Centre, AAFC, Winnipeg, MB to determine end-use suitability for the Canada Western Red Spring (CWRS) market class.

The best 39 families each with four lines per family were grown as the $\mathrm{F}_{4 ; 5}$ generation in $2 \mathrm{~m}$ long head-rows near Irwell, NZ. The $\mathrm{F}_{5}$ families were selected on the basis of grain quality and kernel attributes assayed on the grain from the $\mathrm{F}_{4}$ yield trial. Experimental $\mathrm{F}_{5}$ lines within 
acceptable families were selected on the same basis as in the $F_{3}$ generation. In the $F_{4: 6}$ generation, 100 lines were grown in agronomic trials near Swift Current, Indian Head, and Regina SK, following a protocol similar to that of the $\mathrm{F}_{4}$ generation. Each $\mathrm{F}_{4: 6}$ genotype was also grown in a nursery near Portage La Prairie, MB using a similar protocol as the $\mathrm{F}_{4}$ generation. Five spikes were collected from plots of each $\mathrm{F}_{6}$ line grown near Swift Current. Grain samples from harvested plots were measured for grain yield weight. Grain protein concentration and volume weight of each $\mathrm{F}_{6}$ line were measured in the same way as in the $\mathrm{F}_{4}$ generation on a whole grain sample within each location.

Twenty-eight families of four lines per family, selected from the yield trial plots at Swift Current prior to harvest, were grown as $\mathrm{F}_{7}$ head-rows near Irwell, NZ. Families were selected on the basis of grain quality and kernel attributes assayed on grain from the $\mathrm{F}_{6}$ yield trial. In the $\mathrm{F}_{6: 8}$ generation, 38 lines were grown in agronomic trials near Swift Current, Indian Head, and near Sutherland SK, at the University of Saskatchewan Kernen Research Farm. Grain was harvested and processed in a similar manner to grain from $\mathrm{F}_{4}$ plots. In the $\mathrm{F}_{8}$ generation, response to $\mathrm{FHB}$ was assessed in an inoculated nursery near Carman, MB using the protocol described by Bokore et al. (2017). Selected $\mathrm{F}_{8}$ lines were screened for reaction to a T2, T9, T10, and T39 mixture of races of loose smut [Ustilago tritici (Pers.) Rostr.] (Nielsen 1987), and races L16 and T19 of common bunt. Through this breeding process the experimental line B0418-JB41A met all selection criteria at each generation.

B0418-JB41A was evaluated in the Western Bread Wheat A_3 test in 2009, Western Bread Wheat B test in 2010, and entered in the Western Bread Wheat Cooperative (WBWC) test from 2011 to 2012 as BW957, and in the ICMS Private Wheat Registration (ICMS PR) test in 2013. Annually, the WBWC consisted of 25 experimental lines and five check cultivars grown in 
a 5 x 6 lattice design with three replications at up to 13 locations per year. The check cultivars were Carberry (DePauw et al. 2011), Katepwa (Campbell and Czarnecki 1987), Laura (DePauw et al. 1988), Lillian (DePauw et al. 2005) and CDC Kernen (Hucl 2012). The check cultivars in the 2013 ICMS PR test were 5603HR (Anonymous 2017a), Carberry, Glenn (Mergoum et al. 2006), Lillian, and CDC Kernen (Anonymous 2017b). The variables measured and protocols followed in the WBWC test and the ICMS PR test were described in the operating procedures of the Prairie Recommending Committee for Wheat, Rye and Triticale (Anonymous 2013; http://www.pgdc.ca/committees_wrt.html). The MIXED procedure of SAS ${ }^{\circledR}$ (Littell et al. 2006) was used to perform yearly and multi-year analyses for agronomic data with years, environments, and their interactions considered random effects and cultivar treated as a fixed effect. Mean separation tests were performed using Fisher's protected Least Significant Difference (LSD) procedure.

Response to several diseases was assessed in specialized uniform disease nurseries from 2011 to 2013. Stem rust seedling reaction was assessed using six stem rust races: QTHJF (C25), RHTSC (C20), RKQSC (C63), RTHJF (C57), TMRTF (C10), and TPMKC (C53) (Roelfs and Martens 1988; Fetch et al. 2015), while representative leaf rust races found the previous year were applied to determine seedling leaf rust reaction (McCallum and Seto-Goh 2006). Field evaluations of leaf and stem rust reactions, using leaf rust races representative of those found the previous year and the same stem rust races as for the seedling tests, were conducted annually in epiphytotic nurseries near Glenlea and Winnipeg, MB. Reaction to FHB was assessed in artificially inoculated field tests conducted annually near Glenlea and Carman, MB, Ottawa, ON, Lévis, QC, and Charlottetown, PE (Gilbert and Woods 2006). To determine the response to loose smut, a mixture of the prevalent races T2, T9, T10, and T39 was injected into florets at 
anthesis of plants grown in the field, and the inoculated seed subsequently grown out and rated for disease incidence in a greenhouse (Menzies et al. 2003). To determine the response to common bunt, a mixture of prevalent races L1, L16, T1, T6, T13, and T19 was used to inoculate the seed and planted in mid-April of each year near Lethbridge, AB (Gaudet and Puchalski 1989). The race designations are those described by Nielsen (1987) for loose smut and Hoffmann and Metzger (1976) for common bunt.

A grain sample of BW957 and the check cultivars from each location was submitted to the Canadian Grain Commission to determine grain grade and protein concentration. End-use suitability was determined on a composite sample made up from sites with grain samples representative only of the top hard red spring wheat grades available. The quantity of grain from a location was adjusted to achieve a final composite protein concentration approximating that of the average for the crop that year. A consistent quantity of grain within a location for all experimental lines was used to make up the composite each year. All end-use suitability analyses were performed by personnel at the Grain Research Laboratory, Canadian Grain Commission, Winnipeg, MB following protocols of the AACC (American Association of Cereal Chemists, 2000).

\section{Performance and Adaptation:}

Averaged over 24 trials in two years, AAC W1876 yielded within the range of the checks (Table 1). In the 2013 ICMS PR test, there was no significant difference in yield between AAC W1876 and any of the checks (Table 2). AAC W1876 matured within the range of the checks in the WBWC (Table 3). It was the latest to mature in the ICMS PR test, however, there were no significant differences (Table 4). AAC W1876 is a semidwarf cultivar with plant height significantly shorter than all of the checks except Carberry. AAC W1876 displayed significantly 
lower lodging than Katepwa and Laura (Table 3) and significantly less lodging than 5603HR and Lillian (Table 4).

AAC W1876 had higher test weight than Laura and Lillian (Table 3). The kernel size of AAC W1876 was within the range of the checks and greater than Laura in WBWC, and greater than 5603HR in ICMS PR test. AAC W1876 had a grain protein concentration within the range of the checks (Table 7).

AAC W1876 expressed resistance to prevalent races of leaf rust, moderate resistance stem rust, and intermediate resistance to yellow rust (Puccinia striiformis f. tritici Eriks), common bunt, and loose smut (Table 5). AAC W1876 tended to have lower FHB symptoms than Laura or Lillian and expressed intermediate resistance (Table 6).

\section{Other Characteristics}

SPIKE: Tapering to parallel sided, medium density, nodding to inclined attitude at maturity, strong glaucosity, chaff colour at maturity white to blond, medium length awns.

LOWER GLUME: Glabrous with medium width, medium to long length.

LOWER GLUME SHOULDER: Medium width elevated to strongly elevated with second point present

KERNEL: Hard red type, medium red colour, medium size, oval to broad elliptical shape, rounded to angular cheek shape, narrow and shallow crease, and medium to long brush hairs. GERM: Medium to large, round in shape.

END-USE SUITABILITY: In general, AAC W1876 had quality attributes within the range of the check cultivars (Tables 7 and 8). Relative to the mean of the five checks, AAC W1876 expressed improved flour yield and lower flour ash. AAC W1876 is eligible for grades of 
CWRS.

\section{Maintenance and Distribution of Pedigreed Seed:}

The 108 Breeder Lines originate from random $\mathrm{F}_{6: 12}$ single plants of B0418-JB41A grown as 108 pre-Breeder-Lines in $3 \mathrm{~m}$ long rows in isolation near Swift Current in 2010 and again as $15 \mathrm{~m}$ rows near Indian Head in 2013. Breeder Seed will be maintained by the Seed Increase Unit of the Research Farm, Indian Head, SK S0G 2K0. AAC W1876 has been released to Warburton's Ltd for subsequent Identity Preserved contract production through Warburton Foods Canada, 409 McKay Street. St. Francois Xavier, MB R4L 1A9, Canada. www.warburons.co.uk. The distribution and multiplication of pedigreed seed stocks will be handled through a sub-license to Canterra Seeds, 201 - 1475 Chevrier Boulevard, Winnipeg, MB R3T 1Y7. www.canterra.com.

\section{Acknowledgements}

We gratefully acknowledge the financial support of the Producer funded Wheat Check-off (administered by the Western Grains Research Foundation); M. Steinley and B. Coward for statistical analysis support; D. Niziol and J. Fehr of AAFC, Cereal Research Centre (CRC) (Winnipeg, MB) for providing end-use quality analyses; J. Gilbert of AAFC, CRC for FHB reactions; J. Menzies of AAFC, CRC for loose smut evaluation; D. Gaudet and T. Despins of AAFC, Lethbridge Research Centre for providing reaction to common bunt; S. Fox, G. Humphreys and D. Brown of AAFC, CRC for agronomic assessment and FHB nursery at Portage la Prairie; A. Brûlé-Babel of the University of Manitoba for FHB evaluations at Carman; P. Hucl of the Crop Development Centre, University of Saskatchewan for co-ordinating the 
Western Bread Wheat B test and agronomic assessment at the Kernen research farm; N. Edwards and B.X. Fu of the Grain Research Laboratory, Canadian Grain Commission, Winnipeg, MB for end-use quality assessment; D. Gehl of AAFC Seed Increase Unit, Indian Head, SK for multiplication of Breeder seed; G. McClare, J. Powell, S. Friesen, D. Finley, T. Greenwood, M. Olfert, J. Ross, L. Oakman, H. Campbell, and all members of the wheat genetic enhancement group at AAFC, Swift Current; M. Knelsen, AAFC Regina, SK; O. Thompson, AAFC Indian Head, SK; and B. Beres and R. Dyck, AAFC, Lethbridge, AB, for their assistance in conducting field trials. We are thankful to the members of the wheat molecular genetics lab at AAFC Swift Current for molecular markers associated with fusarium head blight and leaf rust applied to the parents.

\section{References}

American Association of Cereal Chemists. 2000. Approved Methods of the AACC, 10th Ed. St. Paul, MN.

Anonymous. 2013. Operating Procedures, Prairie Recommending Committee for Wheat, Rye and Triticale. [Online]. Available at: http://www.pgdc.ca/pdfs/wrt/201314\%20PRCWRT\%20Operating\%20Procedures_May 2013.pdf. Anonymous 2017a: 5603HR http://www.inspection.gc.ca/english/plaveg/pbrpov/cropreport/whe/app00007330e.shtml Anonymous 2017b: CDC Kernen http://www.inspection.gc.ca/english/plaveg/pbrpov/cropreport/whe/app00007709e.shtml. Bokore, F. E., Knox, R. E., DePauw, R. M., Clarke, F., Cuthbert, R. D., Campbell, H. L., BrûléBabel, A. L., Gilbert, J. and Ruan, Y. 2017. Validation of molecular markers for use with adapted sources of fusarium head blight resistance in wheat. Plant Disease 101:1292-1299. 
http://dx.doi.org/10.1094/PDIS-10-16-1421-RE.

Campbell, A.B. and Czarnecki, E. 1987. Katepwa hard red spring wheat. Can. J. Plant Sci. 67: 229-230. doi:10.4141/cjps87-027.

DePauw, R.M., Knox, R.E., McCaig, T.N., Clarke, F. and Clarke, J.M. 2011. Carberry hard red spring wheat. Can J. Plant Sci. 91: 529-534. doi:10.4141/cjps10187.

DePauw, R.M., Townley-Smith, T.F., Humphreys, G., Knox, R.E., Clarke, F.R. and Clarke, J.M. 2005. Lillian hard red spring wheat. Can. J. Plant Sci. 85: 397- 401. doi:10.4141/P04-137.

DePauw, R.M., Townley-Smith, T.F., McCaig, T.N. and Clarke, J.M. 1988. Laura hard red spring wheat. Can. J. Plant Sci. 68: 203-206. doi:10.4141/cjps88-020.

Fetch, T., Mitchell Fetch, J. \& Xue, A. 2015. Races of Puccinia graminis on wheat, oat, and barley in Canada in 2009 and 2010. Can. J. Plant Pathol. 37: 476-484. DOI:

Fowler, D.B. 1997. CDC Kestrel winter wheat. Can. J. Plant Sci. 77: 673-675. doi:10.4141/P96193.

Frohberg, R.C., Stack, R.W, Oslon, T., Miller, J.D., and Mergoum, M. 2006. Registration of ‘Alsen’ wheat. Crop Sci. 46:2311-2312. doi:10.2135/cropsci2005.12.0501.

Gaudet, D.A. and Puchalski, B.L. 1989. Races of common bunt (Tilletia caries and T. foetida) of wheat in western Canada, Can. J. Plant Pathol. 11: 415-418.

http://dx.doi.org/10.1080/07060668909501089.

Gilbert, J. and Woods, S. 2006. Strategies and considerations for multi-location FHB screening nurseries. Pages 93-102. in T. Ban, J.M. Lewis, and E.E. Phipps, eds. The global fusarium initiative for international collaboration: A strategic planning workshop held at CIMMYT, El Batàn, Mexico; March 14-17, 2006. Mexico, D.F.: CIMMYT.

Graf, R. J., Potts, D. A., Hucl, P. and Hanson, K. M. 2003. Prodigy hard red spring wheat. Can. 
J. Plant Sci. 83: 813 - 816. https://doi.org/10.4141/P02-168.

Hoffmann, J.A. and Metzger, R.J. 1976. Current status of virulence genes and pathogenic races of the wheat bunt fungi in the northwestern USA. Phytopathology 66: 657-660. doi:10.1094/Phyto-66-657.

Hucl, P. 2012. CDC Kernen. Plant Varieties Journal. Number 84. http://www.inspection.gc.ca/english/plaveg/pbrpov/cropreport/whe/app00007709e.shtml Littell, R. C., Milliken, G. A., Stroup, W. W. and Wolfinger, R. D. 2006. SAS ${ }^{\circledR}$ system for mixed models. 2nd ed. SAS Institute, Inc., Cary, NC.

McCallum, B. D. and Seto-Goh, P. 2006. Physiologic specialization of Puccinia triticina, the causal agent of wheat leaf rust, in Canada in 2004. Can. J. Plant Pathol. 28: 566-576. http://dx.doi.org/10.1080/07060660609507335.

Menzies, J.G., Knox, R.E., Nielsen, J. and Thomas, P.L. 2003. Virulence of Canadian isolates of Ustilago tritici: 1964-1998, and the use of the geometric rule in understanding host differential complexity. Can. J. Plant Pathol. 25: 62-72. http://dx.doi.org/10.1080/07060660309507050. Mergoum, M., Frohberg, R.C., Stack, R.W., Olson, T., Friesen, T.L. and Rasmussen, J.B. 1006. Registration of 'Glenn' Wheat. Crop Sci. 46: 473 -474.

Nielsen, J. 1987. Races of Ustilago tritici and techniques for their study. Can. J. Plant Pathol. 9: 91-105. http://dx.doi.org/10.1080/07060668709501888.

Roelfs, A.P. and Martens, J.W. 1988. An international system of nomenclature for Puccinia graminis f. sp. tritici. Phytopathology 78: 525-533. doi:10.1094/Phyto-78-526.

SAS Institute Inc. 2003. SAS Software. Version 9. SAS Institute Inc. Cary, NC, USA. Williams, P.C. 1979. Screening wheat for protein and hardness by near infrared reflectance spectroscopy. Cereal Chem. 56: 169-172. 
Table 1. Grain yield $\left(\mathrm{kg} \mathrm{ha}^{-1}\right)$ of AAC W1876 compared with check cultivars in the Western Bread Wheat Cooperative test 2011-2012.

\begin{tabular}{|c|c|c|c|c|c|c|c|}
\hline & \multicolumn{2}{|c|}{ Zone $1^{\mathrm{a}}$} & \multicolumn{2}{|c|}{ Zone 2} & \multicolumn{2}{|c|}{ Zone 3} & Mean $^{\text {b }}$ \\
\hline & 2011 & 2012 & 2011 & 2012 & 2011 & 2012 & 2011-12 \\
\hline Katepwa & 3336 & 2845 & 4185 & 2825 & 5920 & 3689 & 3683 \\
\hline Laura & 3600 & 2822 & 4451 & 2587 & 5468 & 3114 & 3615 \\
\hline Lillian & 3562 & 2622 & 4398 & 2768 & 6163 & 3413 & 3723 \\
\hline Carberry & 3401 & 2989 & 4576 & 2891 & 6205 & 4236 & 3954 \\
\hline CDC Kernen & 3727 & 3213 & 4645 & 3117 & 6597 & 4030 & 4095 \\
\hline Mean of checks & 3525 & 2898 & 4451 & 2838 & 6071 & 3696 & 3814 \\
\hline AAC W1876 & 3823 & 2702 & 4422 & 2927 & 6129 & 3679 & 3839 \\
\hline $\operatorname{LSD}_{0.05}{ }^{\mathrm{c}}$ & 371 & 663 & 406 & 284 & 578 & 584 & 263 \\
\hline No. of tests & 2 & 2 & 8 & 7 & 2 & 3 & 24 \\
\hline
\end{tabular}

${ }^{\mathrm{a}}$ Zone 1 Locations: Swift Current and Stewart Valley; Zone 2 Locations: Dundurn, Goodale, Indian Head, Kernen. Scott, Lethbridge, Vulcan, and Watrous; Zone 3 Locations: Lacombe, Melfort, and Ellerslie.

${ }^{\mathrm{b}}$ Means based on LSMEANS procedure of SAS.

${ }^{\mathrm{c}}$ LSD, least significant difference $(\mathrm{P} \leq 0.05)$ includes the appropriate genotype $\times$ environment interaction variation. 
Table 2. Grain yield $\left(\mathrm{kg} \mathrm{ha}^{-1}\right)$ of AAC W1876 compared with check cultivars in the ICMS Private Wheat Registration test 2013.

\begin{tabular}{|l|c|c|c|c|}
\hline & Zone $^{\mathrm{a}}$ & Zone 2 & Zone 3 & Mean $^{\mathrm{b}}$ \\
\hline 5603HR & 4751 & 3375 & 4245 & 3971 \\
\hline Glenn & 4586 & 2761 & 4247 & 3662 \\
\hline Carberry & 4860 & 2722 & 4427 & 3766 \\
\hline Lillian & 4795 & 2832 & 4069 & 3681 \\
\hline Unity & 4825 & 3392 & 4290 & 4010 \\
\hline Check Mean & 4763 & 3016 & 4256 & 3818 \\
\hline AAC W1876 & 4804 & 2753 & 4082 & 3652 \\
\hline LSD $_{0.05}{ }^{\mathrm{c}}$ & 660 & 834 & 803 & 573 \\
\hline No. of tests & 2 & 4 & 3 & 9 \\
\hline
\end{tabular}

${ }^{\mathrm{a}}$ Zone 1 Locations: Swift Current and Stewart Valley; Zone 2 Locations: Dundurn, Indian Head, Lethbridge, Saskatoon. Zone 3 Locations: Fort Saskatchewan, Portage La Prairie, Thornhill.

${ }^{\mathrm{b}}$ Means based on LSMEANS procedure of SAS.

${ }^{\mathrm{c}}$ LSD, least significant difference $(\mathrm{P} \leq 0.05)$ includes the appropriate genotype $\times$ environment interaction variation. 
Table 3. Means ${ }^{\mathrm{a}}$ for agronomic characteristics of AAC W1876 compared with the check cultivars in the Western Bread Wheat Cooperative test, 2011-2012.

\begin{tabular}{|l|c|c|c|c|c|c|}
\hline & $\begin{array}{c}\text { Maturity } \\
(\mathrm{d})\end{array}$ & $\begin{array}{c}\text { Height } \\
(\mathrm{cm})\end{array}$ & $\begin{array}{c}\text { Lodging } \\
(1-9)\end{array}$ & $\begin{array}{c}\text { Volume } \\
\text { weight } \\
\left(\mathrm{kg} \mathrm{h}^{-1}\right)\end{array}$ & $\begin{array}{c}\text { Seed mass } \\
(\mathrm{mg})\end{array}$ & $\begin{array}{c}\text { Protein } \\
(\%)\end{array}$ \\
\hline Katepwa & 98.6 & 95.8 & 3.3 & 78.6 & 32.3 & 14.5 \\
\hline Laura & 101.1 & 94.9 & 3.2 & 77.6 & 30.1 & 14.8 \\
\hline Lillian & 98.9 & 93.8 & 2.7 & 77.5 & 34.8 & 15.6 \\
\hline Carberry & 103.0 & 80.9 & 1.3 & 79.8 & 33.2 & 14.7 \\
\hline CDC Kernen & 101.1 & 95.5 & 1.9 & 78.9 & 34.6 & 14.8 \\
\hline AAC W1876 & 102.4 & 82.1 & 1.8 & 78.8 & 33.4 & 15.1 \\
\hline LSD ${ }_{0.05}^{c}$ & 1.7 & 2.2 & 1.1 & 1.1 & 1.7 & 0.7 \\
\hline No. of tests & 21 & 23 & 9 & 25 & 25 & 25 \\
\hline
\end{tabular}

${ }^{a}$ Means based on LSMEANS procedure of SAS.

${ }^{\mathrm{b}}$ Straw strength rated on a scale of 1 to 9 , where $1=$ all plants in plot are erect and $9=$ all plants in a plot are lying horizontal.

${ }^{\mathrm{c}} \mathrm{LSD}$, least significant difference $(\mathrm{P} \leq 0.05)$ includes the appropriate genotype $\times$ environment interaction variation. 
Table 4. Means ${ }^{\mathrm{a}}$ for agronomic characteristics of AAC W1876 compared with the check cultivars in the ICMS Private Wheat Registration test 2013.

\begin{tabular}{|c|c|c|c|c|c|}
\hline & $\begin{array}{l}\text { Maturity } \\
\text { (d) }\end{array}$ & $\begin{array}{l}\text { Height } \\
(\mathrm{cm})\end{array}$ & $\begin{array}{c}\text { Lodging }^{\mathrm{b}} \\
(1-9)\end{array}$ & $\begin{array}{l}\text { Volume weight } \\
\left(\mathrm{kg} \mathrm{hL}^{-1}\right)\end{array}$ & $\begin{array}{c}\text { Seed mass } \\
(\mathrm{mg})\end{array}$ \\
\hline $5603 \mathrm{HR}$ & 101.5 & 103 & 2.5 & 77.1 & 33.4 \\
\hline Glenn & 101.6 & 92 & 1.5 & 80.5 & 36.0 \\
\hline Carberry & 101.5 & 85 & 1.1 & 77.8 & 36.4 \\
\hline Lillian & 100.0 & 99 & 2.4 & 75.7 & 37.6 \\
\hline Unity & 100.5 & 101 & 1.6 & 78.3 & 35.1 \\
\hline Check Mean & 101.0 & 96 & 1.8 & 77.9 & 35.7 \\
\hline AAC W1876 & 103.1 & 87 & 1.1 & 76.9 & 36.9 \\
\hline $\mathrm{LSD}_{0.05}{ }^{\mathrm{c}}$ & 3.1 & 2 & 1.0 & 3.0 & 2.8 \\
\hline No. of tests & 8 & 9 & 5 & 9 & 9 \\
\hline
\end{tabular}

${ }^{\mathrm{a}}$ Means based on LSMEANS procedure of SAS.

${ }^{\mathrm{b}}$ Straw strength rated on a scale of 1 to 9 , where $1=$ all plants in plot are erect and $9=$ all plants in a plot are lying horizontal.

${ }^{\mathrm{c}}$ LSD, least significant difference $(\mathrm{P} \leq 0.05)$ includes the appropriate genotype $\times$ environment interaction variation. 
Table 5. Reactions of AAC W1876 and check cultivars to leaf, stem, and yellow rust, common bunt, and loose smut in the 2011 and 2012 Western Bread Wheat Cooperative test grown at various locations.

\begin{tabular}{|c|c|c|c|c|c|c|c|c|c|c|c|c|c|c|c|c|c|c|c|c|c|c|}
\hline & \multirow{2}{*}{\multicolumn{4}{|c|}{$\begin{array}{c}\text { Field leaf rust } \\
\text { Glenlea } \\
\end{array}$}} & \multicolumn{6}{|c|}{ Field stem rust } & \multirow{2}{*}{\multicolumn{4}{|c|}{$\begin{array}{l}\text { Yellow rust } \\
\text { Lethbridge }\end{array}$}} & \multirow{2}{*}{\multicolumn{4}{|c|}{$\begin{array}{c}\text { Common bunt } \\
\text { Lethbridge }\end{array}$}} & \multirow{2}{*}{\multicolumn{4}{|c|}{$\begin{array}{c}\text { Loose Smut } \\
\text { Glenlea }\end{array}$}} \\
\hline & & & & & \multirow{2}{*}{\multicolumn{2}{|c|}{$\begin{array}{c}\text { Portage } \\
2011 \\
\end{array}$}} & \multirow{2}{*}{\multicolumn{2}{|c|}{$\begin{array}{c}\text { Winnipeg } \\
2011\end{array}$}} & \multirow{2}{*}{\multicolumn{2}{|c|}{$\begin{array}{c}\text { Glenlea } \\
2012 \\
\end{array}$}} & & & & & & & & & & & & \\
\hline & \multicolumn{2}{|c|}{2011} & \multicolumn{2}{|c|}{2012} & & & & & & & & 11 & & 12 & & 11 & 201 & & & 11 & & 12 \\
\hline & 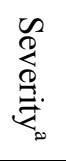 & 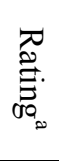 & 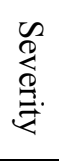 & 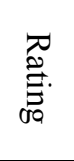 & 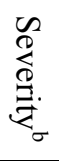 & 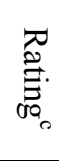 & 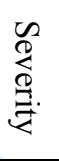 & 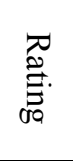 & 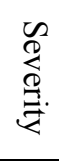 & 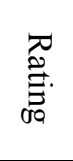 & 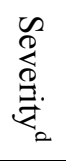 & 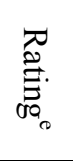 & 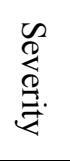 & 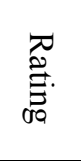 & 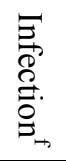 & 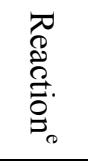 & 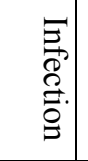 & 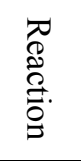 & 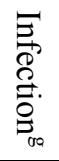 & 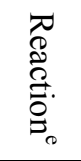 & 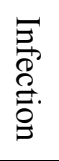 & $\begin{array}{l}\overparen{0} \\
\stackrel{0}{0} \\
\stackrel{0}{0} \\
\stackrel{0}{\Xi}\end{array}$ \\
\hline Katepwa & 30 & I & 57 & MS & 5 & $\mathrm{R}$ & 10 & MR & 2 & $\mathrm{R}$ & 30 & I & 28 & MS & 22 & I & 26 & I & 0 & $\mathrm{R}$ & 8 & $\mathrm{R}$ \\
\hline Laura & 0 & & 5 & $\mathrm{R}$ & 5 & $\mathrm{R}$ & 10 & $\mathrm{R}$ & 2 & $\mathrm{R}$ & 47 & $\mathrm{~S}$ & 13 & $\mathrm{I}$ & 40 & MS & 41 & $\mathrm{~S}$ & 29 & MR & 24 & MR \\
\hline Lillian & 0.3 & $\mathrm{R}$ & 5 & $\mathrm{R}$ & 5 & $\mathrm{R}$ & 7 & MR & 3 & $\mathrm{R}$ & 2 & $\mathrm{R}$ & 0 & $\mathrm{R}$ & 6 & MR & 31 & MS & 69 & MS & 15 & $\mathrm{R}$ \\
\hline Carberry & 0 & $\mathrm{R}$ & 8 & $\mathrm{R}$ & 5 & $\mathrm{R}$ & 10 & MR & 5 & $\mathrm{R}$ & 10 & $\mathrm{R}$ & 3 & $\mathrm{R}$ & 1 & MR & 6 & $\mathrm{R}$ & 5 & $\mathrm{R}$ & 67 & MS \\
\hline CDC Kernen & 0 & & 27 & MR & 5 & $\mathrm{R}$ & 1 & $\mathrm{R}$ & 10 & MR & 47 & $\mathrm{~S}$ & 33 & MS & 23 & $\mathrm{I}$ & 32 & MS & 0 & $\mathrm{R}$ & 4 & $\mathrm{R}$ \\
\hline AAC W1876 & $\operatorname{Tr}$ & & 5 & $\mathrm{R}$ & 5 & $\mathrm{R}$ & 5 & $\mathrm{R}$ & 10 & $\mathrm{I}$ & 18 & $\mathrm{I}$ & 5 & $\mathrm{I}$ & 14 & $\mathrm{I}$ & 22 & $\mathrm{I}$ & 6 & $\mathrm{R}$ & 47 & $\mathrm{I}$ \\
\hline LSD & & & & & & & & & & 1 & 24 & & 10 & & 10 & & 13 & & & & & \\
\hline
\end{tabular}

${ }^{a}$ Severity is the percentage of leaf area affected by leaf rust; Rating is the descriptive classification of disease resistance/susceptibility based on percent severity where $\mathrm{R}$ (resistant) $=0$ - $10 \%$, MR (moderately resistant) $=11-30 \%$, I (intermediate resistance) $=31-39 \%$, MS (moderately susceptible) $=40-60 \%$, and S (susceptible) $>60 \%$.

${ }^{\mathrm{b}}$ Severity is the percentage of the stem infected with stem rust using the Modified Cobb Scale.

${ }^{\mathrm{C}}$ Disease response categories: $\mathrm{R}=$ resistant, $\mathrm{MR}=$ moderately resistant, $\mathrm{I}=$ intermediate, $\mathrm{MS}=$ =moderately susceptible, and $\mathrm{S}=$ susceptible.

${ }^{d}$ Severity is the percentage of leaf area affected by yellow rust.

Disease reaction categories: $\mathrm{R}=$ =resistant, $\mathrm{MR}=$ moderately resistant, $\mathrm{I}=$ intermediate, $\mathrm{MS}=$ =moderately susceptible, and $\mathrm{S}=$ susceptible.

Percentage of spikes with common bunt symptoms.

${ }^{g}$ Percentage of plants with loose smut symptoms. 
Table 6. Response to fusarium head blight and the mycotoxin deoxynivalenol (DON) of AAC W1876 and check cultivars based on the 2011 and 2012 Western Bread Wheat Cooperative test grown in inoculated nurseries near Glenlea and Carman, MB, Ottawa, ON,

Levis, QC and Charlottetown, PE.

\begin{tabular}{|c|c|c|c|c|c|c|c|c|c|c|c|c|c|c|c|c|c|c|c|c|c|c|}
\hline & \multicolumn{9}{|c|}{ Glenlea } & \multirow{2}{*}{\multicolumn{4}{|c|}{$\begin{array}{c}\text { Carman } \\
2012\end{array}$}} & \multicolumn{2}{|c|}{ Ottawa } & Levis & \multicolumn{6}{|c|}{ PEI } \\
\hline & \multicolumn{5}{|c|}{2011} & \multicolumn{4}{|c|}{2012} & & & & & \multirow{2}{*}{ 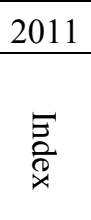 } & \multirow{2}{*}{ 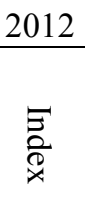 } & \multirow{2}{*}{$\begin{array}{l}2011 \\
\qquad \begin{array}{c}\overrightarrow{2} \\
\stackrel{8}{x}\end{array}\end{array}$} & \multicolumn{3}{|c|}{2011} & \multicolumn{3}{|c|}{2012} \\
\hline & 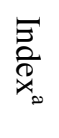 & 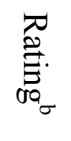 & $\bigoplus_{0}$ & $\overrightarrow{\tilde{\sigma}}$ & 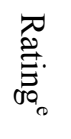 & $\overrightarrow{\bar{Z}}$ & 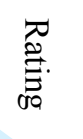 & 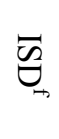 & 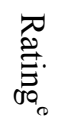 & $\frac{\vec{Z}}{\ddot{2}}$ & 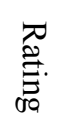 & 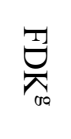 & $\stackrel{\nabla}{Z}$ & & & & 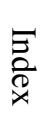 & $\stackrel{\ominus}{Z}$ & $\underset{\widetilde{Z}}{\vec{\pi}}$ & 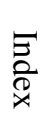 & $\underset{\pi}{\pi}$ & $\stackrel{\ominus}{Z}$ \\
\hline Katepwa & 16 & MS & 1.6 & 3.3 & I & 16 & MS & 18 & I & 33 & $\mathrm{I}$ & 16.3 & - & 48 & 50 & 65 & 68 & 13.4 & 8 & 48 & 8 & 1.0 \\
\hline Laura & 16 & MS & 4.8 & 24.9 & I & 6 & MR & 14 & MR & 48 & MS & 15.9 & 15 & 48 & 72 & 79 & 87 & 35.2 & 9 & 53 & 8 & 0.7 \\
\hline Lillian & 41 & $\mathrm{~S}$ & 10.7 & 8.2 & $\mathrm{~S}$ & 11 & $\mathrm{I}$ & 17 & I & 76 & $\mathrm{~S}$ & 22.8 & 32 & 73 & 77 & 90 & 83 & 13.9 & 7 & 54 & 7 & 1.7 \\
\hline Carberry & 6 & MR & 3.2 & 2.7 & MR & 11 & $\mathrm{I}$ & 17 & $\mathrm{I}$ & 15 & MR & 3.9 & 5.6 & 22 & 32 & 32 & 44 & 17.6 & 7 & 45 & 6 & 0.2 \\
\hline CDC Kernen & 11 & I & 4.5 & 20.8 & I & 8 & MR & 15 & I & 26 & I & 14.6 & - & 27 & 45 & 57 & 55 & 11.9 & 7 & 52 & 6 & 1.8 \\
\hline AAC W1876 & 2 & $\mathrm{R}$ & 2.5 & 10.0 & $\mathrm{R}$ & 26 & $\mathrm{~S}$ & 24 & MS & 25 & $\mathrm{I}$ & 13 & & 30 & 38 & 65 & 43 & 15.6 & 5 & 43 & 4 & 1.7 \\
\hline
\end{tabular}

${ }^{a}$ Fusarium head blight disease index $=$ (percentage of infected heads $\mathrm{x}$ percentage of diseased florets on infected heads) $/ 100$.

${ }^{b}$ Disease response category: $\mathrm{R}=$ resistant, $\mathrm{MR}=$ moderately resistant, $\mathrm{I}=$ intermediate in reaction, $\mathrm{MS}=$ moderately susceptible, $\mathrm{S}=$ susceptible.

${ }^{\mathrm{c}} \mathrm{DON}$, deoxynivalenol (ppm).

2011 Incidence Severity DON Index $=[(0.3 *$ Incidence $)+(0.3 *$ Severity $)+(0.4 * \mathrm{DON})]$.

${ }^{e}$ Response rating based on ISD.

${ }^{f} 2012$ Incidence Severity DON Index $=[(0.2 *$ Incidence $)+(0.2 *$ Severity $)+(0.6 * \mathrm{DON})]$. The ISD was changed to place greater weight on DON

${ }^{g}$ FDK $=$ Fusarium damaged kernels on a weight of kernels with Fusarium symptoms as a percent of the total sample weight.

${ }^{\mathrm{h}}$ Fusarium damaged kernels on a 1 (low) to 10 (high) scale. 
Table 7. End-use suitability a analyses, using a 74\% extraction flour for all flour testing, of AAC W1876, control cultivars, and mean of the control cultivars, based on the Western Bread Wheat Cooperative test 2011 and 2012.

\begin{tabular}{|c|c|c|c|c|c|c|c|c|c|c|}
\hline & $\begin{array}{c}\text { Wheat } \\
\text { protein } \\
(\%)\end{array}$ & $\begin{array}{c}\text { Flour } \\
\text { protein } \\
(\%)\end{array}$ & $\begin{array}{l}\text { Protein } \\
\text { loss }(\%)\end{array}$ & $\begin{array}{c}\text { Hagberg } \\
\text { Falling No. } \\
\text { (s) }\end{array}$ & $\begin{array}{l}\text { Amylo- } \\
\text { graph } \\
\text { viscosity } \\
(\mathrm{BU})^{\mathrm{b}}\end{array}$ & $\begin{array}{c}\text { Flour } \\
\text { yield } \\
0.50 \text { ash } \\
(\%)\end{array}$ & $\begin{array}{c}\text { Flour } \\
\text { ash (\%) }\end{array}$ & $\begin{array}{c}\text { Flour } \\
\text { colour }^{\mathrm{c}} \\
\mathrm{L}^{*}\end{array}$ & $\begin{array}{l}\text { Starch damage } \\
\text { (megazeme) }\end{array}$ & $\begin{array}{c}\text { Particle } \\
\text { size index }\end{array}$ \\
\hline Laura & 14.1 & 13.2 & 0.9 & 443 & 648 & 76.8 & 0.45 & 94.8 & 7.5 & 56.0 \\
\hline Lillian & 14.6 & 14.0 & 0.7 & 430 & 568 & 73.8 & 0.51 & 94.1 & 8.6 & 55.0 \\
\hline Carberry & 14.0 & 13.1 & 0.9 & 398 & 583 & 77.3 & 0.44 & 94.3 & 8.7 & 52.5 \\
\hline CDC Kernen & 13.8 & 13.3 & 0.5 & 455 & 550 & 77.5 & 0.43 & 94.2 & 8.7 & 54.0 \\
\hline Check Mean & 14.1 & 13.3 & 0.7 & 432 & 584 & 76.2 & 0.46 & 94.3 & 8.5 & 54.2 \\
\hline AAC W1876 & 14.2 & 13.5 & 0.7 & 415 & 590 & 78.3 & 0.42 & 94.5 & 7.9 & 55.5 \\
\hline $\mathrm{SD}^{\mathrm{d}}$ & 0.05 & 0.05 & 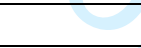 & 15 & 5 & 0.34 & 0.005 & 0.9 & 0.08 & 0.9 \\
\hline
\end{tabular}

\begin{tabular}{|c|c|c|c|c|c|c|c|c|c|c|c|}
\hline & \multicolumn{4}{|c|}{ Farinograph } & \multicolumn{7}{|c|}{ Canadian short process (150 ppm ascorbic acid) } \\
\hline Entry & $\begin{array}{c}\text { Absorption } \\
(\%)\end{array}$ & $\begin{array}{l}\mathrm{DDT}^{\mathrm{e}} \\
(\mathrm{min})\end{array}$ & $\mathrm{MTI}^{\mathrm{f}}$ & $\begin{array}{l}\text { Stability } \\
\text { (min) }\end{array}$ & $\begin{array}{c}\text { Baking } \\
\text { absorption } \\
(\%)\end{array}$ & $\begin{array}{c}\text { Mixing } \\
\text { energy }^{\mathrm{g}} \\
\left(\mathrm{W}-\mathrm{h} \mathrm{kg}^{-1}\right)\end{array}$ & $\begin{array}{l}\text { Mixing } \\
\text { time } \\
(\min ) \\
\end{array}$ & $\begin{array}{l}\text { Loaf } \\
\text { volume } \\
\text { (cc) }\end{array}$ & Appearance & $\begin{array}{c}\text { Crumb } \\
\text { structure }\end{array}$ & $\begin{array}{c}\text { Crumb } \\
\text { color }\end{array}$ \\
\hline Katepwa & 68.1 & 6.5 & 13.5 & 15.0 & 67.0 & 6.6 & 3.2 & 1043 & 7.5 & 6.3 & 7.8 \\
\hline Laura & 67.2 & 8.5 & 16.0 & 12.5 & 67.0 & 7.4 & 3.6 & 1110 & 7.6 & 6.1 & 7.9 \\
\hline Lillian & 70.1 & 5.1 & 8.3 & 25.0 & 69.0 & 6.1 & 3.1 & 1080 & 7.4 & 6.0 & 7.4 \\
\hline Carberry & 67.5 & 6.6 & 10.3 & 25.0 & 67.0 & 8.2 & 4.1 & 1065 & 7.4 & 6.1 & 7.8 \\
\hline CDC Kernen & 68.0 & 5.9 & 11.8 & 22.5 & 68.0 & 7.7 & 3.8 & 1058 & 7.5 & 6.5 & 7.8 \\
\hline Check Mean & 68.2 & 6.5 & 12.0 & 20.0 & 67.6 & 7.2 & 3.5 & 1071 & 7.5 & 6.2 & 7.7 \\
\hline AAC W1876 & 66.6 & 7.5 & 18.8 & 17.5 & 66.0 & 8.6 & 3.9 & 1138 & 7.6 & 6.0 & 7.7 \\
\hline $\mathrm{SD}^{\mathrm{d}}$ & 0.2 & 0.4 & 2.6 & 1.4 & $\mathrm{NA}^{\mathrm{e}}$ & 0.3 & 0.2 & 45 & $\mathrm{NA}^{\mathrm{h}}$ & NA & NA \\
\hline
\end{tabular}

${ }^{\mathrm{a}}$ American Association of Cereal Chemists methods were followed by the Grain Research Laboratory, Canadian Grain Commission for determining the various end-use suitability traits on a composite of 6 to 10 locations each year.

${ }^{\mathrm{b}}$ Amylograph viscosity expressed in Brabender Units (BU).

c Flour color by spectrophotometer colour $\mathrm{L}^{*}=$ brightness on the CIE scale.

${ }^{\mathrm{d}} \mathrm{SD}$ is the standard deviation based on repeated testing of Allis mill check samples, and standard bake flour sample with replicate tests carried out over an extended period of time each season, provided by Grain Research Laboratory, Canadian Grain Commission.

${ }^{\mathrm{e}}$ DDT is the Farinograph dough development time measured in minutes.

${ }^{f}$ MTI is the Farinograph mixing tolerance index.

${ }^{g}$ Mixing energy expressed as watts hour per $\mathrm{kg}$.

${ }^{\mathrm{h}}$ NA not available. 
Table 8. End-use suitability ${ }^{\mathrm{a}}$ analyses, using a 74\% extraction flour for all flour testing, of AAC W1876, control cultivars, and mean of the control cultivars, based on the ICMS Private Wheat Registration test 2013.

\begin{tabular}{|l|c|c|c|c|c|c|c|c|}
\hline & $\begin{array}{c}\text { Wheat } \\
\text { protein } \\
(\%)\end{array}$ & $\begin{array}{c}\text { Flour } \\
\text { protein } \\
(\%)\end{array}$ & $\begin{array}{c}\text { Protein } \\
\text { loss }(\%)\end{array}$ & $\begin{array}{c}\text { Hagberg } \\
\text { Falling No. } \\
(\mathrm{s})\end{array}$ & $\begin{array}{c}\text { Amylo- } \\
\text { graph } \\
\text { viscosity } \\
(\mathrm{BU})\end{array}$ & $\begin{array}{c}\text { Flour } \\
\text { yield } \\
0.50 \text { ash } \\
(\%)\end{array}$ & $\begin{array}{c}\text { Flour } \\
\text { ash }(\%)\end{array}$ & $\begin{array}{c}\text { Starch damage } \\
(\mathrm{megazeme})\end{array}$ \\
\hline Unity & 12.2 & 11.4 & 0.8 & 438 & 840 & 79.6 & 0.43 & 20.5 \\
\hline Glenn & 12.5 & 12.1 & 0.4 & 398 & 780 & 76.5 & 0.45 & 18.4 \\
\hline Carberry & 13.2 & 12.1 & 1.1 & 401 & 570 & 79.5 & 0.44 & 20.6 \\
\hline Lillian & 13.4 & 12.9 & 0.5 & 484 & 660 & 77.7 & 0.48 & 20.2 \\
\hline 5603HR & 11.9 & 11.6 & 0.3 & 437 & 670 & 75.2 & 0.48 & 19.0 \\
\hline Check Mean & 12.6 & 12.0 & 0.6 & 431 & 704 & 77.7 & 0.45 & \\
\hline AAC W1876 & 13.4 & 12.5 & 0.9 & 438 & 580 & 81.3 & 0.42 & 19.7 \\
\hline SD & 0.05 & 0.05 & & 15 & 5 & 0.34 & 0.005 & 20.6 \\
\hline
\end{tabular}

\begin{tabular}{|c|c|c|c|c|c|c|c|c|}
\hline & \multicolumn{4}{|c|}{ Farinograph } & \multicolumn{4}{|c|}{ No time dough baking ${ }^{f}$} \\
\hline Unity & 60.8 & 4.90 & 41 & 5.7 & 62 & 4.6 & 118 & 864 \\
\hline Glenn & 63.5 & 6.40 & 34 & 8.1 & 65 & 4.4 & 144 & 882 \\
\hline Carberry & 61.8 & 4.40 & 42 & 5.7 & 63 & 3.4 & 134 & 871 \\
\hline $5603 \mathrm{HR}$ & 58.1 & 4.50 & 33 & 7.1 & 60 & 4.9 & 113 & 895 \\
\hline Check Mean & 61.5 & 4.88 & 37 & 6.6 & 63 & 4.1 & 128 & 882 \\
\hline AAC W1876 & 60.9 & 5.00 & 31 & 6.9 & 63 & 3.2 & 137 & 958 \\
\hline $\mathrm{SD}^{\mathrm{c}}$ & 0.2 & 0.4 & 2.6 & 1.4 & $\mathrm{NA}^{\mathrm{h}}$ & NA & NA & NA \\
\hline
\end{tabular}

${ }^{\mathrm{a}}$ American Association of Cereal Chemists methods were followed by the Grain Research Laboratory, Canadian Grain Commission for determining the various enduse suitability traits on a composite of 6 to 10 locations each year.

${ }^{\mathrm{b}}$ Amylograph viscosity expressed in Brabender Units (BU).

${ }^{\mathrm{c}} \mathrm{SD}$ is the standard deviation based on repeated testing of Allis mill check samples, and standard bake flour sample with replicate tests carried out over an extended period of time each season, provided by Grain Research Laboratory, Canadian Grain Commission.

${ }^{\mathrm{d}}$ DDT is the Farinograph dough development time measured in minutes.

${ }^{\mathrm{e}}$ MTI is the Farinograph mixing tolerance index.

${ }^{\mathrm{f}}$ AACCI method (10 -10.03).

${ }^{\mathrm{g}}$ Mixing energy expressed as watts hour per $\mathrm{kg}$.

${ }^{\mathrm{h}}$ NA not available. 